\title{
APPLICATION OF GIS IN THE ASSESSMENT OF FLOOD RISK IN THE REGION ZENICA - DOBOJ CANTON
}

\author{
Aida KORJENIĆl (iD), Edin HRELJA ${ }^{1}$, Amina SIVAC ${ }^{1}$, Amra BANDA ${ }^{1}$ (i)
}

DOI : 10.21163/GT_2021.162.07

\begin{abstract}
:
Flood represents a temporary cover of water that submerges land, usually not covered by water, which is caused by water overflowing the watercourses. The floods that occur in the area of Zenica-Doboj Canton in Bosnia and Herzegovina cause massive damage to agriculture, housing, equipment and civil engineering facilities and can be characterized as hazards. The hydrographic backbone of this Canton is the river Bosna, and the subject of research in this paper is the flood vulnerability in Zenica-Doboj Canton. The result of the work is the production of flood hazard and risk maps using GIS. Geographic Information System (GIS)-based spatial analysis and visual elements have been used frequently in recent years for detection of flood hazard areas and preparation of maps. GIS applications are based on a database and analysis tools which have logical and mathematical relationships between the layers. When creating the flood hazard map, in addition to GIS tools, Hec-RAS was also used as a program intended for the analysis of hydraulic calculations. The results of this paper are of great importance for spatial planning and environmental protection, starting with local communities, municipalities and the entire Canton.
\end{abstract}

Key-words: Spatial analysis, the Bosnia River, Flood risk, GIS, Physical geography

\section{INTRODUCTION}

GIS is a data management system that shows different data sets on the same map, such as land use, construction, environmental, groundwater and topography (Ozkan, Tarhan, 2015). GIS and hydraulic models have been recommended for studying flood analysis and flood prediction (Györiet al., 2016, Haidu et al., 2017). Geographic Information System (GIS) mapping applications vary to flood hazard mapping, flood hazard management, hydrological data storing and management. Especially, a combination of GIS (Geographic Information System) and HEC-RAS (Hydrologic Engineering Center-River Analysis System) has a great capability in the simulation of flood hazard maps (Kim et al., 2020). Out of all-natural hazards in the world, flood is the mostcommon one. River flood results from the water level overtop, both natural and artificial, of theriverbank, which disturbs human life and properties (Koem, Tantanee, 2021). Flood hazard in rivers can be characterized by the probability and intensity of high river flows and their consequent inundations, and it depends on the atmospheric and catchment processes preceding river flood generation (Merz et al., 2010).

Urban floods are one of the most devastating natural disasters globally, and improved flood prediction is essential for better flood management. Today, high-resolution real-time datasets for flood-related variables are widely available (Khan, He, Valeo, 2018). Urbanization and industrialization have led to changes in land tenure over time. Urbanization has caused the increase in impermeable surfaces that contribute significantly to surface runoff, with the most important role going to Effective Impermeable Surfaces (Haidu, Ivan, 2016). Among naturaldisasters, floods have been the most common in terms of frequency, threat level and caused damage (Gavrilović et al., 2012; Petrović et al., 2015) and this problem has become relevant after several major floods in various parts of Europe and the world in the last decade of the twentieth century, followed by high damage and loss of life. In recent decades, almost a third of all human victims of natural disasters in the world are flood victims, and material damage is estimated at tens of billions of dollars (Jovanović, et al., 2009).

\footnotetext{
${ }^{1}$ University of Sarajevo, Faculty of Science, Department of Geography, 71000 Sarajevo, Bosnia and Herzegovina,aida.k@pmf.unsa.ba, edinhrelja@pmf.unsa.ba, amina.sivac@pmf.unsa.ba, amra.banda@pmf.unsa.ba
} 
Trend analyses show that major flood disasters as well as damages and losses generated by them have increased drastically in recent years (Berz, 2000; Barredo, 2007). Because of the accelerated pace of anthropogenic activity, hazard frequency and intensity is exacerbated, requiring immediate delivery of science-based solutions for mitigation, resilience, and adaptation that can be quickly deployed in any hazard-prone area (Allen-Dumas, Xu, Kurte, Rastogi, 2021). Mitigating these urban water hazards is challenging for watershed management and the urban planning community (Eriksson et al., 2015). Speaking of the causes of floods in recent times, we must point to climate change,because the strongest floods are caused by climatic phenomena such as heavy rainfall, melting snow or their combination (Školjić, Hodžić, 2018). The amount of precipitation, their spatial distribution, intensity and duration are the basic climatological causes of floods. In addition to these causes, the occurrence of floods is also contributed by the capacity of watercourses or watercourse networks to receive and further transmit water runoff, before the onset of precipitation, soil cover and topography (Imamović, 2015). According to the causes, floods can also occur due to the accumulation of ice in streams, landslides or earthquakes, demolition of dams or other anthropogenic effects (Mandych, 2010). Bonacci (2003) states that the natural cause of floods can also be the leakage of water at the mouths of rivers due to waves. Depending on the time of the formation of a water wave, the floods can be calm, torrential and accidental. Calm floods are those of large rivers where it takes ten or more hours to form a water wave. There are torrential floods on mountain watercourses where the water wave is formed in less than ten hours, while accidental floods occur mainly with the demolition of water management or hydropower facilities, and are characterized by the current formation of a large water wave.

Flood risk is a combination of the probability of a flood event and the possible harmful consequences of a flood event for human health, the environment, cultural heritage and economic activity (Jabučar, Lukovac, 2015). It is a measure of the potential damage that could occur when and if flooding occurs and is determined by the "overlap" of spatial data on the elements of hazard on the one hand and the locations of potentially endangered categories on the other.

\subsection{Floods in Zenica-Doboj Canton}

Analysis of the average water level for a multi - year period shows that the river Bosna and its tributaries in the area of Zenica - Doboj Canton have the annual distribution of average water levels, which corresponds to the distribution of precipitation during the year. This can also be seen in the example of the Maglaj area (Table 1), (Hydrometeorological Institute of Federation of B\&H).

Table 1.

Values of average monthly precipitation $(\mathrm{mm})$ and water level $(\mathrm{cm})$

for period 1961 - 1990 (MS Maglaj).

\begin{tabular}{|c|c|c|c|c|c|c|c|c|c|c|c|c|}
\hline & $\boldsymbol{I}$ & $\boldsymbol{I I}$ & $\boldsymbol{I I I}$ & $\boldsymbol{I V}$ & $\boldsymbol{V}$ & $\boldsymbol{V I}$ & $\boldsymbol{V I I}$ & $\boldsymbol{V I I I}$ & $\boldsymbol{I X}$ & $\boldsymbol{X}$ & $\boldsymbol{X I}$ & $\boldsymbol{X I I}$ \\
\hline $\mathrm{P}(\mathrm{mm})$ & 51.5 & 47.5 & 54.3 & 62.6 & 76.1 & 84.5 & 63.5 & 69.1 & 64.9 & 66.7 & 74.5 & 67.4 \\
\hline $\mathrm{H}(\mathrm{cm})$ & 151.1 & 143.4 & 188.7 & 187.3 & 149.8 & 131.9 & 97.15 & 78.3 & 87.7 & 103.5 & 121.3 & 152.7 \\
\hline
\end{tabular}

Source: Hydrometeorological Institute of Federation of Bosnia and Herzegovina (HMIFB\&H)

The rise in water levels is influenced by precipitation and melting snow that occurs in the spring. In contrast, during the summer months, the water levels reach minimum values due to less precipitation, as well as high temperatures and increased evaporation. This annual distribution of water levels for a multi-year period corresponds to the pluvial-nival regime, in which two maxima and two minima stand out. The first maximum is related to the spring period (March-April) and the second to the month of December, while the minimums correspond to the winter (February) and summer seasons (August). Extremely high water levels can occur due to short-term but heavy rains, then as a result of melting snow or high groundwater levels, which can contribute to the likelihood of flooding. The average annual values of flows on the river Bosna in this Canton are $58.6 \mathrm{~m}^{3} / \mathrm{s}$, while the maximum values recorded during May 2014 were $867 \mathrm{~m}^{3} / \mathrm{s}$, resulting severe flooding (Fig. 1). 


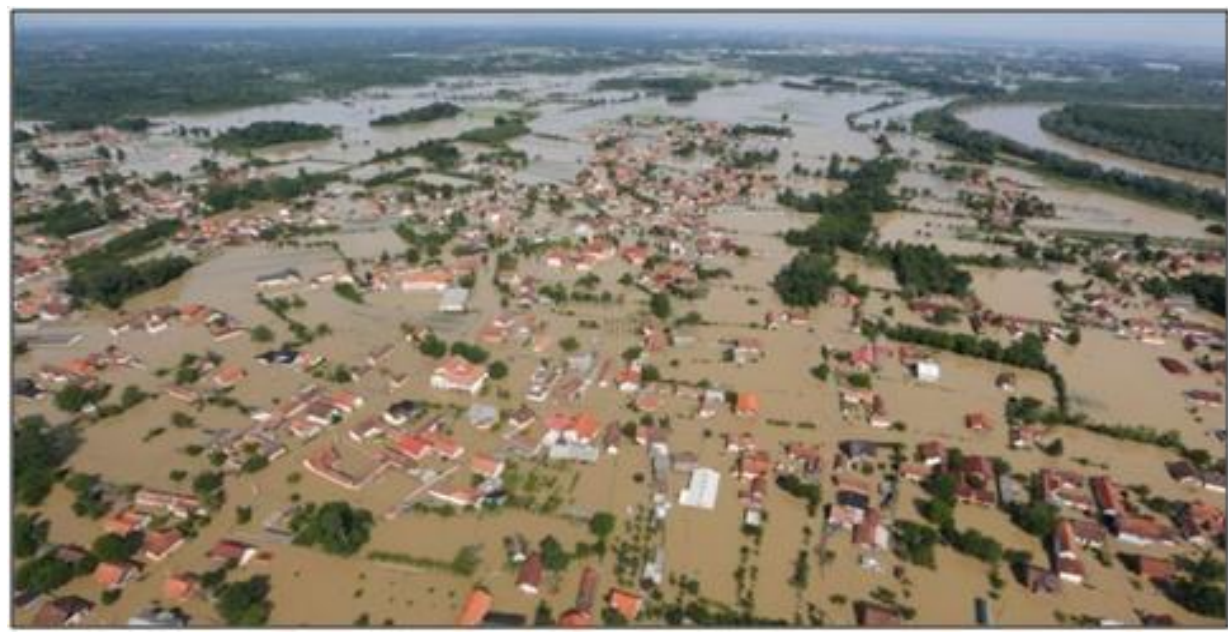

Fig. 1. Flooded area in May 2014, Municipality of Doboj-Jug.

(Source: http://www.dobojjug.ba/contents/893).

It is known that the floods during the mentioned year occurred after continuous precipitation of 5 days, and in some parts of the basin, it was determined that the return period occurred once in 500 years. Maximum flows in May 2014 for the hydrological stations listed in the Table 2, show their relationship to high waters of return periods from 10 to 500 years, Table 3.

Table 2 .

High waters $\left(\mathrm{m}^{3} / \mathrm{s}\right)$ on river Bosna for the hydrological stations Doboj, Maglaj, Zavidovići, Raspotočje and Dobrinje

\begin{tabular}{|l|c|c|c|c|}
\hline \multicolumn{1}{|c|}{$\boldsymbol{H S}$} & $Q_{\max }$ & ${ }_{\min } Q_{\max }$ & ${ }_{\boldsymbol{a v}} Q_{\max }$ & ${ }_{\max } Q_{\max }$ \\
\hline Doboj & $\mathbf{2 0 1 4}$ & \multicolumn{3}{|c|}{$\mathbf{1 9 6 1 - 1 9 9 0}$} \\
\hline Maglaj & 4831 & 556 & 1441 & 2533 \\
\hline Zavidovići & 3579 & 571 & 1032 & 2177 \\
\hline Raspotočje & 2552 & 399 & 802 & 1571 \\
\hline Dobrinje & 1630 & 257 & 608 & 1326 \\
\hline
\end{tabular}

Source: Hydrological yearbook 2014. Hydrometeorological Institute of Republica Srpska (HMIRS) and Hydrometeorological Institute of Federation of Bosnia and Herzegovina (HMIFB\&H).

Table 3.

Probability of occurrence of high waters of return periods from 10 to 500 years.

\begin{tabular}{|c|c|c|c|c|c|}
\hline Return period & Doboj & Maglaj & Zavidovići & Raspotočje & Dobrinje \\
\hline \multicolumn{7}{|c|}{} \\
\hline 10 & 2091 & 1508 & 1164 & 904 & 600 \\
\hline 20 & 2420 & 1764 & 1320 & 1039 & 717 \\
\hline 50 & 2795 & 2120 & 1520 & 1220 & 880 \\
\hline 100 & 3087 & 2479 & 1673 & 1360 & 1058 \\
\hline 500 & 3936 & 3272 & 2091 & 1700 & 1375 \\
\hline
\end{tabular}

Source: Hydrological study for B\&H, Hydrometeorological Institute of Republica Srpska (HMIRS) and Hydrometeorological Institute of Federation of Bosnia and Herzegovina (HMIFB\&H).

In the area of Zenica-Doboj Canton, floods have so far occured on the rivers Bosna, Usora, Krivaja, Gostović, Zgošća, Stavnja, Tešanjka, Bistrička, Liješnica and Papratnica. The hydrographic and hydrological diversity of Zenica-Doboj Canton is the result of a very complex impact of various 
components of the natural environment, such as the geological, geomorphological, climatic, pedological and biogeographical characteristics of this area. In the period 1999-2005, the average damage of floods in Zenica-Doboj Canton was huge to the population. In 2001 alone, floods affected 8 municipalities. The consequence of these floods was enormous material damage caused to road infrastructure, housing and economy facilities, agricultural and other lands, water supply facilities, electricity network, grid network, etc., which was estimated at around 9,500,000.00 EUR ${ }^{2}$. During June 2010, rivers Bosnia and Usora with their tributaries, overflowed and flooded both residential and commercial buildings, causing the most damage in municipalities of Kakanj, Maglaj, Doboj-south and Usora.

During the floods in May 2014, Zenica-Doboj Canton experienced major floods (Fig.1). At that time, heavy rains lasted almost continuously for five days, submerging the soil, which had previously been saturated with water, with extremely high specific flows and runoff coefficients. The floods reached the largest extent on May 15th, 2014, when the flood area between Zavidovići and Modriča was $99 \mathrm{~km}^{2}$, and the volume of floodwater was 401 million $\mathrm{m}^{3}$. Analyzes conducted with international expert support in the countries of the Sava River Basin confirmed that the floods in May 2014 were the largest in the last 120 years (ARSO, 2014). Over 3,000 landslides were triggered, and over 43,000 houses were damaged or destroyed. Based on the report of the Cantonal Commission for Damage Assessment (2015), damage of EUR 190,000,000.00 was caused by this natural disaster in the area of Zenica-Doboj Canton ${ }^{3}$. The floods occurred during February and May 2019, and they were reminiscent of the floods in 2014 but there were no fatalities. However, these floods left a significant mark on agricultural land where farmers were most affected, and 13 landslides were triggered. The occurrence of floods (especially with reference to 2014) was influenced by natural and antropogenic factors, including heavy rainfall (level of 500 annual rainfall), a disorder of watercourses, unplanned antropogenic construction of facilities, bridges, retaining walls, the problem of division of responsibilities for coastal maintenance fortifications, outdated approach in watercourse maintenance, lack of flood protection embankments ${ }^{4}$. In the Zenica-Doboj Canton, continuous water monitoring is performed today, including meteorological, hydrological as well as water quality monitoring. This has created the preconditions for the functioning of prognostic meteorological and hydrologicalhydraulic models within which flood events can be predicted in real-time and timely notification and alerting related to a possible event can be made.

\section{STUDY AREA}

Zenica-Doboj Canton is located in Bosnia and Herzegovina, with an area of 3,328 $\mathrm{km}^{2}$, between $17^{\circ} 44^{\prime} 38^{\prime \prime}$ and $18^{\circ} 50^{\prime} 11^{\prime \prime} \mathrm{E}$, and $43^{\circ} 54^{\prime} 13^{\prime \prime}$ and $44^{\circ} 43^{\prime} 41^{\prime \prime} \mathrm{N}$ (author's calculation based on GIS data) (Fig. 2). Zenica-Doboj Canton consists of ten municipalities in which, according to the last 2013 Census, lives a total of 364,433 inhabitants. The most populated part is along the river Bosna with an average population density of 109.5 inhabitants $/ \mathrm{km}^{2}$ (author's calculation based on GIS and Census data).

2 Assessment of the endangerment of the territory of Zenica-Doboj Canton from natural and other disasters (Procjena ugroženosti teritorije Zeničko-Dobojskog Kantona od prirodnih i drugih nesreća), Zenica. http://www.zdk.ba/sjednicevlade/sjednice2016/63sjednica/63-16 21-07-2016.pdf (Accessed March 28 2021)

3 The Report of the Cantonal Commission for Damage Assessment from Natural and other Damage on Damage assessment in the area of Zenica-Doboj Canton (Izvještaj Komisije za procjenu šteta od prirodnih i drugih neseća o procjeni šteta na području Zeničko-dobojskog kantona) http://zdk.ba/sjednicevlade/sjednice2015/18sjednica/18-04_20-07-2015.pdf (Accessed March 28 2021)

${ }^{4}$ Assessment of the endangerment of the territory of Zenica-Doboj Canton from natural and other disasters (Procjena ugroženosti teritorije Zeničko-Dobojskog Kantona od prirodnih i drugih nesreća), Zenica. http://www.zdk.ba/sjednicevlade/sjednice2016/63sjednica/63-16_21-07-2016.pdf (Accessed March 28 2021) 


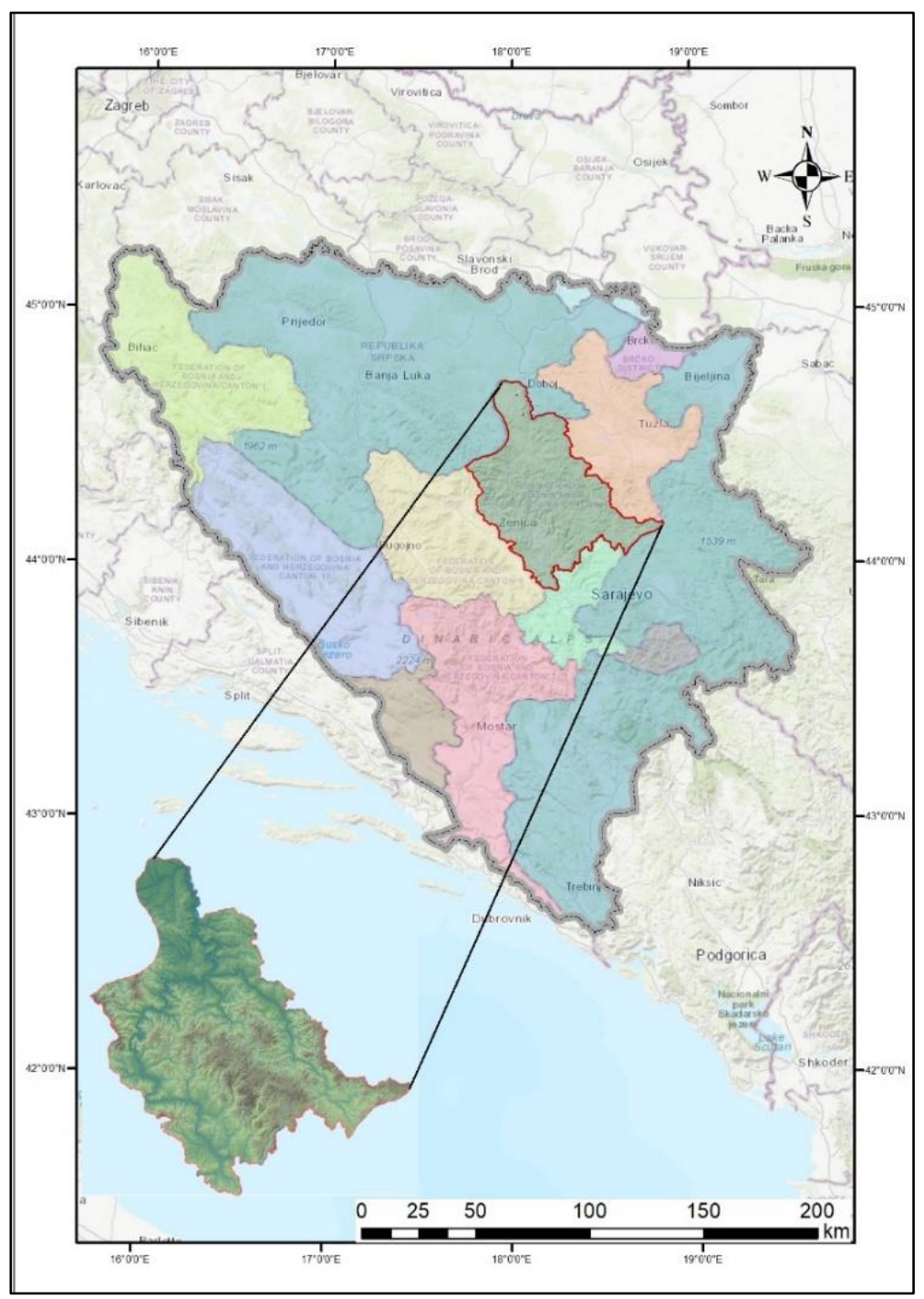

Fig. 2. Geographical position of Zenica - Doboj Canton on the map of Bosnia and Herzegovina.

It belongs to the belt of the inner Dinarides, and the landscape of the Canton is characterized by three hypsometrically specific areas: lowland-hilly in the north in the valley of the river Usora (130 $200 \mathrm{~m}$ asl), hilly-mountainous in the central part $(201-500 \mathrm{~m}$ asl) and hilly in the southern part of the Canton $(501-1473 \mathrm{~m}$ asl). The largest spatial coverage is occupied by the category of inclination from $12^{\circ}$ to $32^{\circ}$, namely $56.04 \%$, followed by the category of inclination from $5^{\circ}$ to $12^{\circ}$, occupying $23.23 \%$ of the total area of the Canton. The category of inclination from $2^{\circ}$ to $5^{\circ}$ or $7.5 \%$ of the total area is followed by the slope category between $32^{\circ}$ and $55^{\circ}$ which occupies $7.2 \%$ of total spatial coverage. The smallest share has the slope category from 0 to $2^{\circ}$ which covers $5.98 \%$ of total area of the Canton (Author's calculation based on GIS digital elevation model data). It is noticeable that larger categories of slopes occur mainly in the central part of the Canton, which is primarily due to the mountainous terrain characteristics. As a result of gravity, torrents are formed on such terrains, which flow towards the watercourses of the second, and then towards the watercourses of the first category.

The area of Zenica-Doboj Canton has a mostly temperate continental climate, and in the higher areas mountain climate. Precipitation is evenly distributed throughout the year (Table 4), with an 
average annual rainfall of $780 \mathrm{~mm}$ in the lowlands to $1000 \mathrm{~mm}$ in the mountainous areas (Author's calculation based on GIS digital elevation model and vertical pluviometric gradient data).

Table 4.

Average monthly precipitation for a period 2004-2014.

\begin{tabular}{|c|c|c|c|c|c|c|c|c|c|c|c|c|}
\hline Month & I & II & III & IV & V & VI & VII & VIII & IX & X & XI & XII \\
\hline $\mathrm{mm}$ & 57.06 & 60.42 & 51.38 & 82.61 & 76.04 & 73.37 & 72.76 & 62.07 & 89.77 & 99.81 & 77.08 & 81.53 \\
\hline
\end{tabular}

Source: Meteorological yearbooks 2004-2014, Hydrometeorological Institute of Federation of Bosnia and Herzegovina $(H M I F B \& H)$

The river Bosna, in the area of the Canton, has larger tributaries, such as: Stavnja, Fojnička river, Trstionica, Zgošća, Ribnica, Lašva, Babina rijeka, Kočeva, Bistričak, followed by Liješnica, Gostović, Krivaja and Usora. In addition to these tributaries, there are several smaller permanent and occasional watercourses flowing into Bosna (Fig. 3).

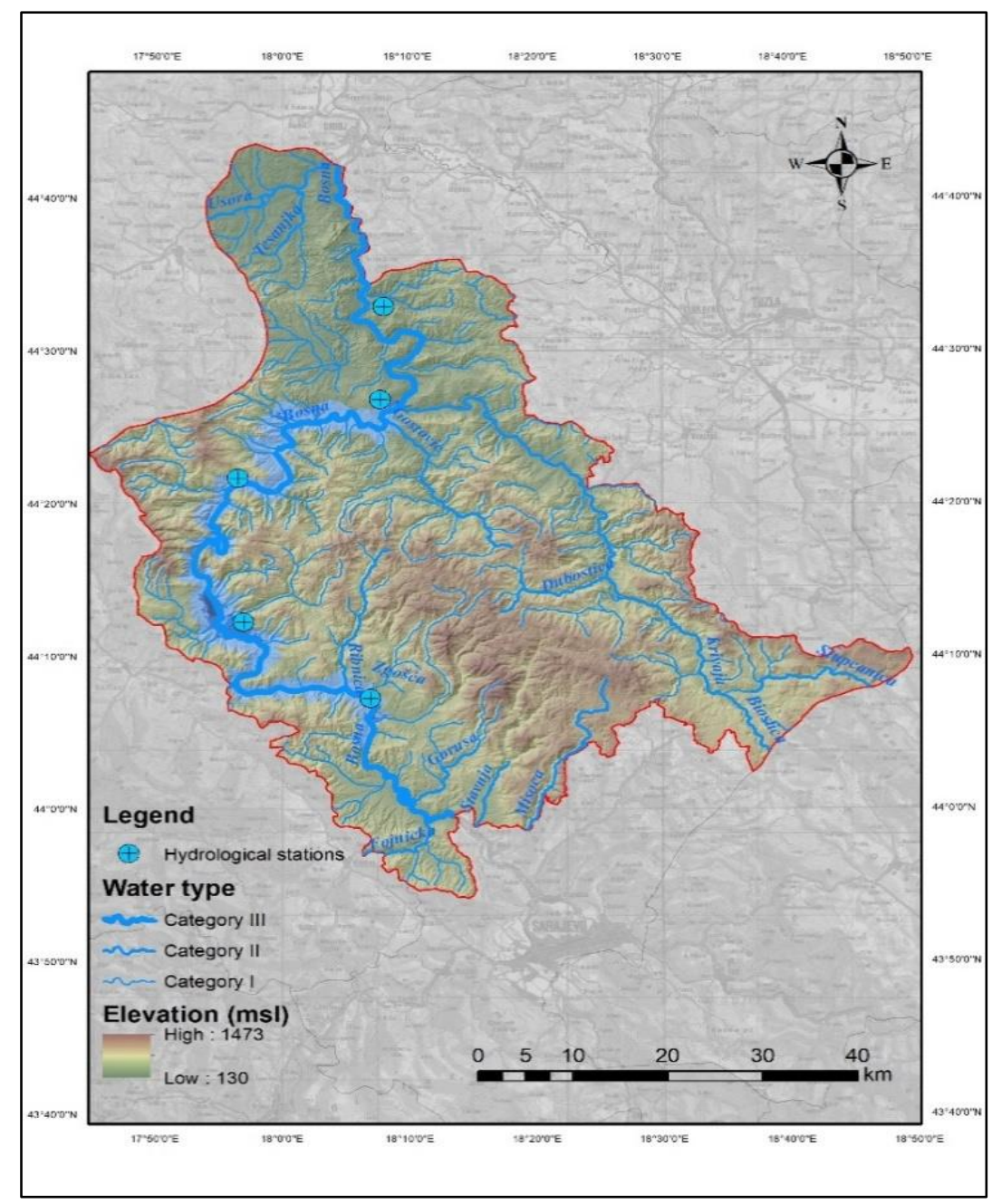

Fig. 3. River Bosna with its tributaries and hydrological stations that were analyzed in Zenica - Doboj Canton. 


\section{DATA AND METHODS}

\subsection{Climate and hydrological data}

Database of meteorological parameters, primarily precipitation and hydrological data on water level and flow, was used in this paper. Meteorological monitoring is the responsibility of the Federal Hydrometeorological Institute in Sarajevo (HMIFB\&H), while the Agency for the Sava River Basin Sarajevo is responsible for hydrological monitoring of surface waters. The data analyzed in this paper are available for the period from 1961 to 1990, after which the measurements were interrupted due to the war in Bosnia and Herzegovina during the 1990s. The second, comparative period of the analyzed data referred to the period from 2004 to 2019.

\subsection{Creating a flood hazard map}

The flood hazard map of Zenica-Doboj Canton contains data on the boundaries of the flood area for floods of different return periods, depth or water level, and it was made in several phases. Flood area covers the surface of $233.74 \mathrm{~km}^{2}$ or $6.95 \%$ of total area of Zenica - Doboj Canton. In the first phase, data on more endangered areas were collected, so the river Bosna and the localities that represent the greatest hazard in the Zenica-Doboj Canton in terms of floods were selected. The final results gave a more accurate location of the flood lines, then the water depth on the profiles. In addition, it is possible to perceive the hazard of floods in planning procedures, as well as the analysis of the load (and stability) of facilities in flood areas.

The HEC-GeoRas extension in ArcMap was used to create the map. First of all, it was necessary to obtain a network of Triangular Irregular Networks (TIN) by converting the DEM terrain model. After that, the main river, Bosna, was digitized, and the river Zgošća was selected as a category I watercourse. The length of the main river that has been cultivated is $85.51 \mathrm{~km}$, i.e. the length of flow from the settlement of Papratnica in the municipality of Kakanj all the way to the municipality of Zavidovići. According to our research, the area upstream from the mouth of the Krivaja river into the Bosna river is the most susceptible area to flooding. In addition to rivers, banks and profiles have been digitized at intervals of 800 meters and a width of 900 meters. The connection of the HEC-RAS program with the ArcMap tools was made through the HEC-GeoRas extension, which provides an efficient exchange of input data and results with the ArcGIS software package. The accuracy of determining the width of flooding of watercourses depends on the quality of the DEM terrain model, which is very important, especially for the mountain-valley area such as in the Zenica-Doboj Canton. The Manning coefficient of resistance was used for the paper, combined with the purpose of the land (Corina Land Cover was used in the paper). Manning's equation and other empirical open-channel flow equations are convenient and commonly-used tools for hydrologists and engineers who seek to solve practical problems of channel design, flood wave modelling, and fluvial sediment transport (Dingman, 2009). In research settings, applications of these equations include assessing flow in drainage canals and indirectly estimating peak flood discharges (Lumbroso and Gaume, 2012).

Manning's roughness coefficient (or Gauckler-Manning coefficient) is one of the energy loss coefficients, i.e. it describes the energy loss due to friction of water and open watercourse beds (LozziKožar and Kožar, 2009). According to these authors, this coefficient varies considerably and depends on a large number of factors, such as surface roughness, vegetation and overgrowth of the riverbed, canal irregularities, branching or joining of watercourses, obstacles, size and shape of canals, canal slope, water height and flow, seasonal changes, temperature, erosion, suspended material. Selecting the appropriate value of Manning's coefficient is very important for the accuracy of the flow calculation in an open watercourse (Hydrological study of the Bosnia River Basin, 2012). After the coefficient was assigned to each land use category, it was used as input data in the HEC-GeoRas extension. Manning's coefficient is of great importance in determining the risk of floods depending on the purpose of the land in the floodplain. Manning's „n“ values should be calibrated whenever observed water surface elevation information is available. When gaged data are not available, values of „ $\mathrm{n}$ “ computed for similar stream conditions or values obtained from experimental data should be used as guides in selecting „n“ values. There are several references a user can access that show 
Manning's „n“ values for tipical channels (Brunner, 2016). The highest coefficient is assigned to forest areas (0.40), and the lowest to urban areas, landfills and sports and recreational facilities (0.02), where it is concluded that forest areas and vegetation have a much greater impact on water energy loss, which is not the case with urban areas. The maximum flow rate used, $Q=1673.00 \mathrm{~m}^{3} / \mathrm{s}$, was also used for the hydraulic calculation, and a 100-year flood was taken into account.

\subsection{Creating a flood risk map}

The flood risk is the probability of damage in the endangered area. The components of risk are the probability of occurrence (as an indicator of cause) and material damage (as an indicator of consequence) (Jovanović, Todorović, Rodić, 2009).

To produce flood risk maps, it was previously necessary to analyze risk indicators. According Jovanović et al. (2009) there are two parameters to express flood damage: maximum damage (Smax) - the maximum estimated the value of the property for a given area. This is the upper limit of damage ("total damage"), which cannot be achieved even in the event of major floods, the damage factor $(\alpha)$ - an indicator of possible damage, expressed as percentage relative to maximum damage Smax. Variability of this parameter is defined by the "damage function" - the relationship between the depth of flooding and damage to a particular type purpose area. The monetary amount of potential damage, according to the definition of the above parameters, is defined as: $\mathrm{S}=\alpha \cdot \mathrm{Smax}$. Risk indicators are performed with regard to the following categories: population, economy, protected areas, cultural and historical monuments and IPPC facilities. Based on analysis of weight factors in available methodologies of some EU countries, weight factors were adopted. In each category, weighting factors were assigned, namely: population $=0.4$; economy $=0.3$; cultural-historical heritage $=0.1$; protected areas $=0.1$; IPPC plants - out of category (if they are endangered, the risk is $100 \%$ ) (Jabučar, Lukovac, 2015). The formula used in this analysis is:

where:

$$
F R=S n \times T F \times O
$$

$F R$ - risk factor; $S n$ - number of dots, $\mathrm{km}^{2} ; \mathrm{TF}$ - weighting factor; $\mathrm{O}$-flood hazard (see Eq. 2).

It should be noted that the flood hazard was obtained with the assumption that the flood depth is $1 \mathrm{~m}$, the flow rate is $1 \mathrm{~m} / \mathrm{s}$. The adopted value of flood hazard $(\mathrm{O})$ depending on the velocity and depth of the flow is:

$$
O=h \times(v+0.5)
$$

where:

$O$-flood hazard; $h$-flood depth $(\mathrm{m}) ; v$ - flow velocity $(\mathrm{m} / \mathrm{s}) ; 0.5$ - corrective constant (this includes the case of flooding with stagnant water of great depth for which there is an obvious hazard) (Jabucar, Lukovac, 2015).

The risk factor was determined (Table 5), after which each of the listed land uses received its own class based on the risk factor, and then the risk category. Based on the table of risk categories (Table 6,7,8,9,10,11), a summary map of flood risk was made (Fig. 5). The risk factor by categories was determined using the Arc GIS and HEC-RAS programs, as well as on the basis of research by Jovanović et al. (2009).

Table 5.

Tabular presentation of flood risk analysis.

\begin{tabular}{|l|r|r|r|r|}
\hline \multicolumn{1}{|c|}{ Land use } & Sn $\left(\mathbf{k m}^{2}\right)$ & TF & O & FR \\
\hline Economy & 111.42 & 0.3 & 1.5 & 4011.177 \\
\hline Population & 19.42 & 0.4 & 1.5 & 932.1919 \\
\hline Cultural-historical heritage & 0.32 & 0.1 & 1.5 & 3.799128 \\
\hline Protected areas & 98.49 & 0.15 & 1.5 & 1772.731 \\
\hline IPPC & 4.10 & 1 & 1.5 & 491.6624 \\
\hline
\end{tabular}


Table 6.

Risk factor by population category.

\begin{tabular}{|c|c|c|}
\hline Risk factor & Class & Risk category \\
\hline $0-49$ & 0 & Negligible risk \\
\hline $50-499$ & $0<\mathrm{R}<0.25$ & Low risk \\
\hline $500-999$ & $0.26<\mathrm{R}<0.50$ & Moderate risk \\
\hline $1,000-1,499$ & $0.51<\mathrm{R}<0.75$ & High risk \\
\hline$>1,500$ & $0.76<\mathrm{R}<1.0$ & Extreme risk \\
\hline
\end{tabular}

Table 7.

Risk factor by economy category.

\begin{tabular}{|c|c|c|}
\hline Risk factor & Class & Risk category \\
\hline $0-49$ & 0 & Negligible risk \\
\hline $50-249$ & $0<\mathrm{R}<0.33$ & Low risk \\
\hline $250-499$ & $0.34<\mathrm{R}<0.67$ & High risk \\
\hline$>500$ & $0.68<\mathrm{R}<1.0$ & Extreme risk \\
\hline
\end{tabular}

Risk factor according to the category of cultural and historical heritage.

\begin{tabular}{|c|c|c|}
\hline Risk factor & Class & Risk category \\
\hline $0-499$ & 0 & Negligible risk \\
\hline $500-3,499$ & $0<\mathrm{R}<0.25$ & Low risk \\
\hline $3,500-6,999$ & $0.26<\mathrm{R}<0.50$ & Moderate risk \\
\hline $7,000-9,999$ & $0.51<\mathrm{R}<0.75$ & High risk \\
\hline$>10,000$ & $0.76<\mathrm{R}<1.0$ & Extreme risk \\
\hline
\end{tabular}

Risk factor according to the category of protected areas.

Table 9.

\begin{tabular}{|c|c|c|}
\hline Risk factor & Class & Risk category \\
\hline $0-499$ & 0 & Negligible risk \\
\hline $500-1,499$ & $0<\mathrm{R}<0.33$ & Low risk \\
\hline $1,500-2,499$ & $0.34<\mathrm{R}<0.67$ & High risk \\
\hline$>1,500$ & $0.68<\mathrm{R}<1.0$ & Extreme risk \\
\hline
\end{tabular}

Risk factor by category of IPPC plants.

\begin{tabular}{|c|c|c|}
\hline Risk factor & Class & Risk category \\
\hline $0-199$ & 0 & Negligible risk \\
\hline $150-299$ & $0<\mathrm{R}<0.50$ & High risk \\
\hline$>300$ & $0.51<\mathrm{R}<1.0$ & Extreme risk \\
\hline
\end{tabular}

Risk categories for making a summary flood risk map.

Table 11.

\begin{tabular}{|c|c|}
\hline Class $(\mathbf{R F})$ & Risk category \\
\hline 0 & Negligible risk \\
\hline $0<\mathrm{R}<0.25$ & Low risk \\
\hline $0.26<\mathrm{R}<0.50$ & Moderate risk \\
\hline $0.51<\mathrm{R}<0.75$ & High risk \\
\hline $0.76<\mathrm{R}<1.0$ & Extreme risk \\
\hline
\end{tabular}




\section{RESULTS AND DISCUSSIONS}

As a result of the calculation and analysis of the used data, a flood hazard map of Zenica - Doboj Canton (Fig. 4), was made, which contains floods of medium value ( $\mathrm{Tp} \geq 100$ years), flood extent, and water depth (darker color represents depth). The flood risk map (Fig. 4) shows that the areas most exposed to flood hazards are precisely those that have been flooded in the recent past.

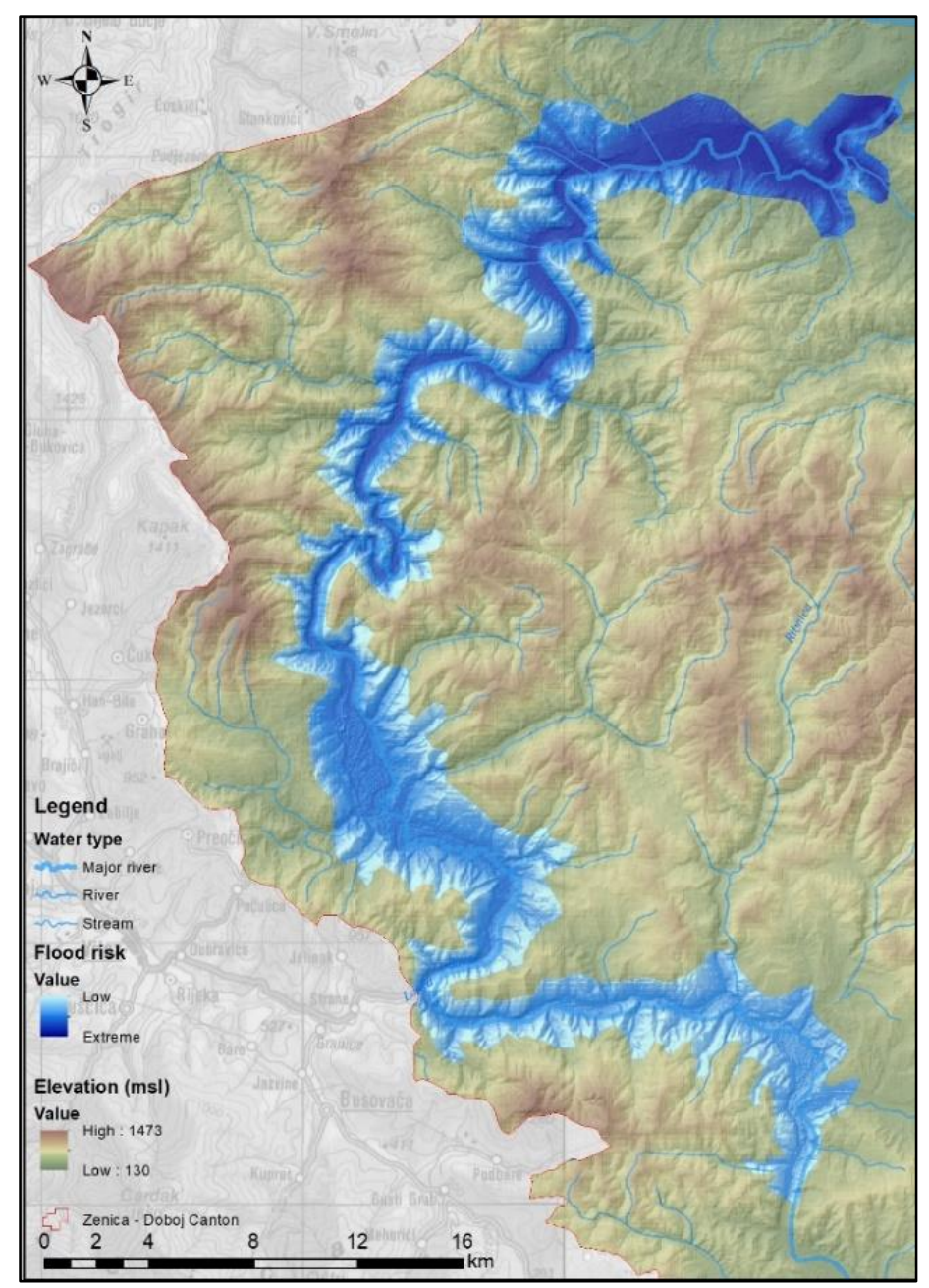

Fig. 4. Flood hazard in the area of Zenica - Doboj Canton.

Further analysis found that extreme flood risk occurs in places that are both the most populated and industrially most important, at least when it comes to this floodplain. The number of the potentially affected population is certainly large if we consider the fact that the highest population density is right next to the river Bosna. In the potentially affected area, there are also various economic activities, but also facilities that could cause sudden environmental pollution in case of floods, especially in the area of the City of Zenica where extreme risk occurs. 
A large number of settlements are located within the floodplain (Fig. 5). Some of them are directly in the category of extreme risk, which means that, due to floods, the population of this area is extremely vulnerable, and the situation is further exacerbated by the proximity of IPPC facilities which would not only endanger the environment but also have a direct impact on population health. The high-risk category mainly includes urban areas with a large population. Smaller, rural-type settlements are at moderate risk. If we analyze the number of inhabitants, according to the 2013 Census, which exists in 62 settlements in this flood coverage, we get the number of 114,005 inhabitants who may be endangered by floods.

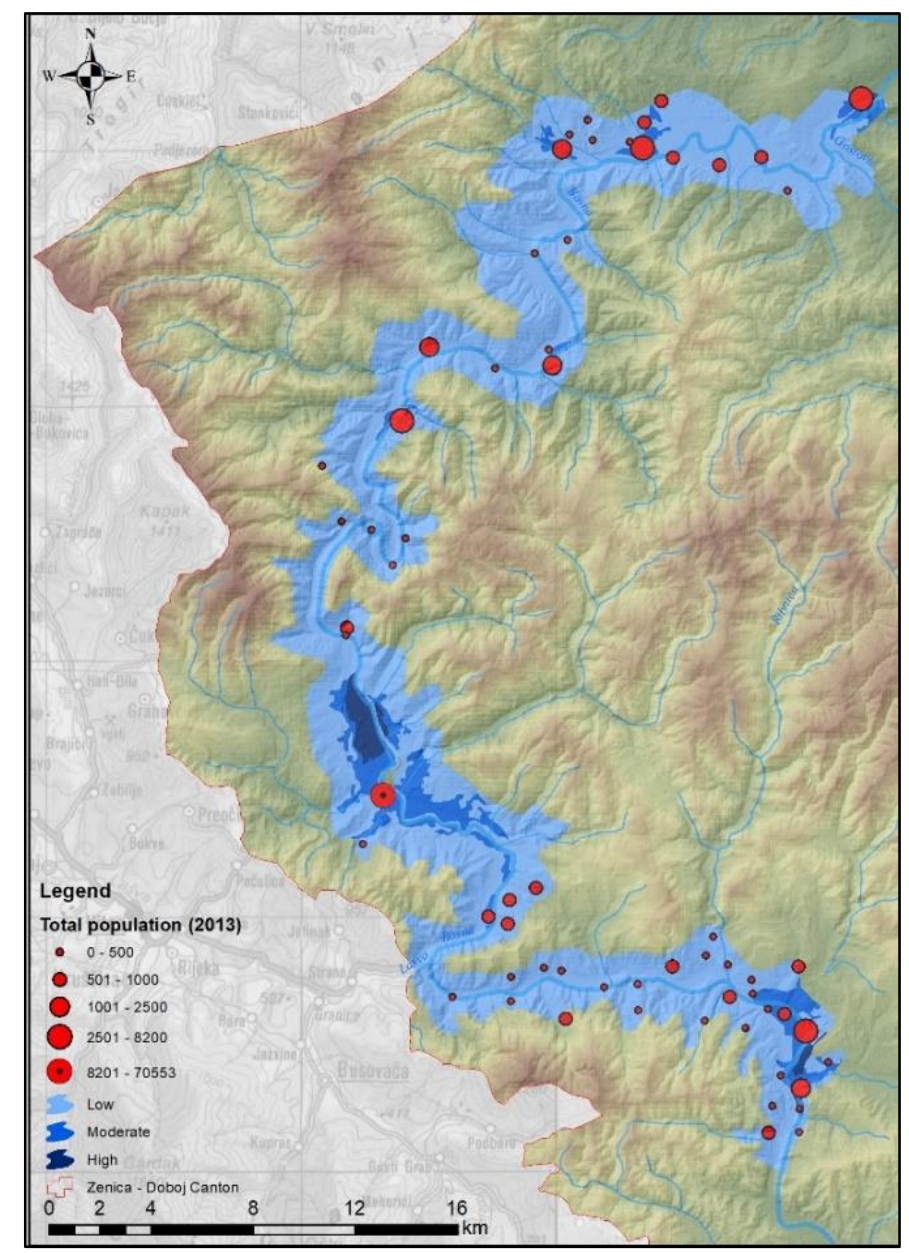

Fig. 5. Distribution of settlements in relation to the risk category of Zenica - Doboj Canton.

Given the purpose of the land represented in the flood zone (Fig. 6), it can be seen that the largest area is occupied by the economy $(47.67 \%)$, protected areas $(42.13 \%)$, followed by the population $(8.31 \%)$, IPPC facilities $(1.75 \%)$ and cultural-historical monuments $(0.14 \%)$. Total flood prone area covers the surface of $233.74 \mathrm{~km}^{2}$. The analyzed area is, among other things, the most economically important, most populated, with a developed industry and road and railway infrastructure, so floods leave a great impact on this area. 
During the work on this paper, the analysis of the spatial coverage of individual land use categories according to the risk category was performed (Fig. 7). Cultural and historical buildings are exposed to negligible risk, with a surface distribution of $0.32 \mathrm{~km}^{2}$. No category of land use belongs to the category of low risk, while a part of the economy and the population are exposed to moderate risk, with a spread of $0.45 \mathrm{~km}^{2}$ and $19.42 \mathrm{~km}^{2}$. Protected areas of $98.49 \mathrm{~km}^{2}$ are exposed to high risk, while the rest of the economy, with a distribution of $110.97 \mathrm{~km}^{2}$, and IPPC plants of $4.1 \mathrm{~km}^{2}$ are exposed to extreme risk.

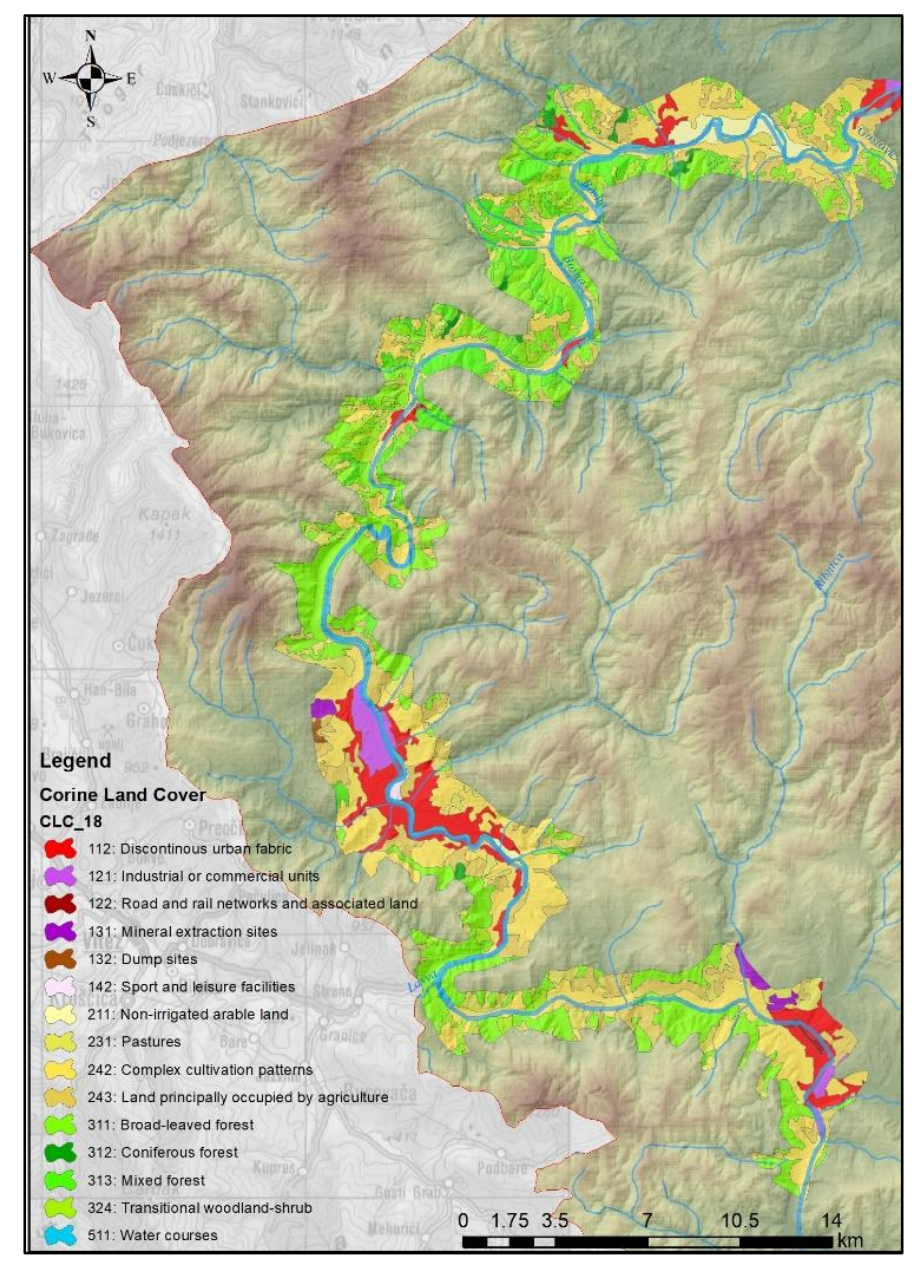

Fig. 6. Categories of land use in the flood zone.

In addition to floods, landslides and escarpments are a significant phenomena, especially in the municipalities of Breza, Kakanj, Vareš and Zenica, where there is intensive ore exploitation. The data show that the areas of the municipalities of Maglaj and Žepče are also exposed to landslides as a result of the removal of vegetation ${ }^{5}$. Very little is being done on afforestation, and often just cleared areas

5 Assessment of the endangerment of the territory of Zenica-Doboj Canton from natural and other disasters, Zenica. http://www.zdk.ba/sjednicevlade/sjednice2016/63sjednica/63-16_21-07-2016.pdf (Accessed March 28 2021) 
have been used for agricultural purposes. Due to intensive urbanization and expansion of settlements, construction is becoming more frequent in protected areas than in floodplains, torrents and exploitation areas, and even in landslide areas.

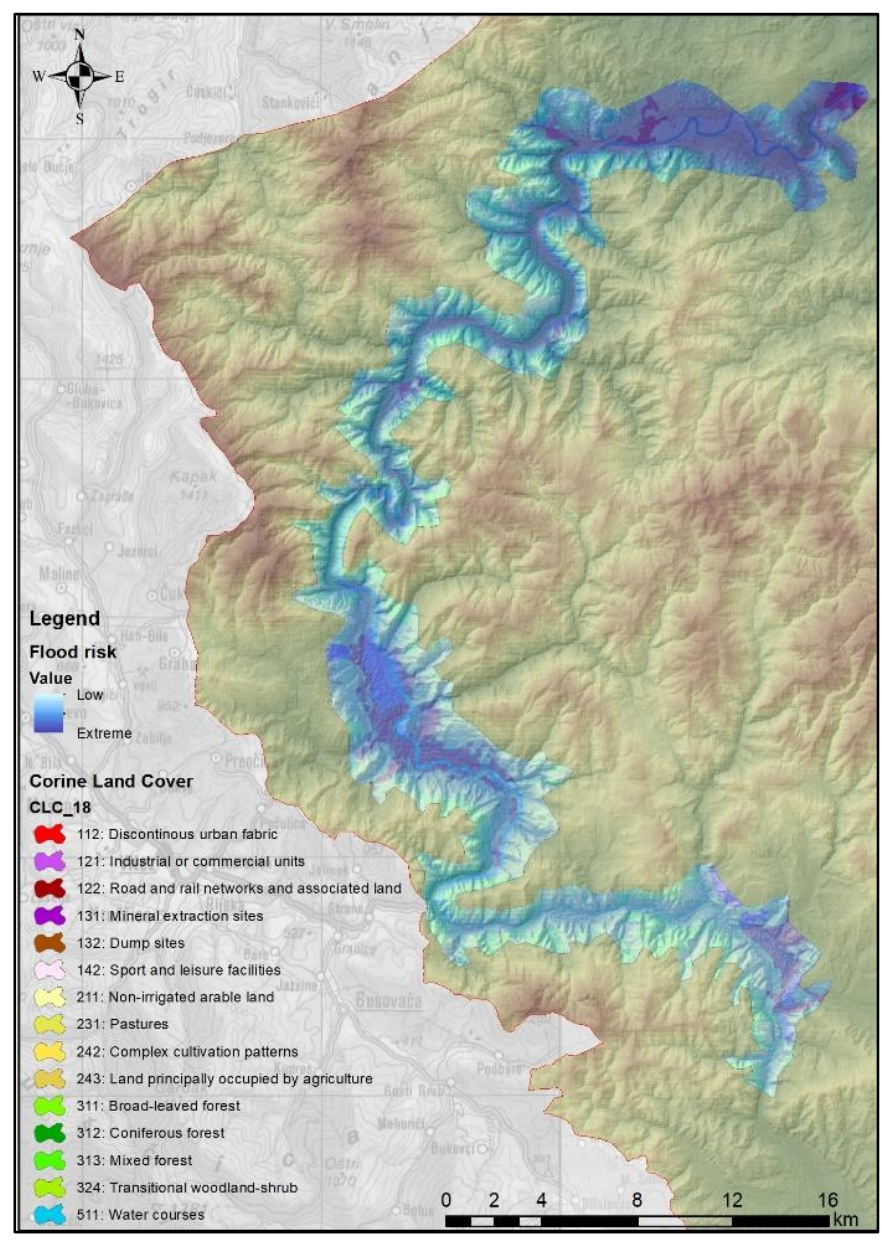

Fig. 7. Synthesis map of land use and flood risk in Zenica-Doboj Canton.

\section{CONCLUSIONS}

Climatic, geological and geomorphological features and landscape are the most important factors for the occurrence of floods in the area of Zenica-Doboj Canton. However, the anthropogenic impact on the environment is even greater than assumed. In support of this thesis we will list only a few anthropogenic factors with exceptional impact on the environment, such as: uncontrolled deforestation, exploitation of minerals, illegal construction, unprofessional irrigation of agricultural land, which directly affected changes in water and soil regime. In the analyzed area, floodplains of tributaries of the river Bosna and tributaries of lower order often coincide. Smaller watercourses are torrential in nature, which is often the catalyst for their higher flow. Particularly critical are the basins of mountain streams from the lower mountains that delimit the valley of the river Bosna. Factors that can affect the reduction of floods or even prevent their occurrence include: regular cleaning and maintenance of watercourses, preparation of studies and other documentation on the state of 
watercourses, installation of flood protection embankments, construction of transverse (stone or concrete) barriers in torrents, afforestation, cultivation of vegetation and prevention of uncontrolled logging, removal of unplanned buildings in a narrow flood zone, construction of protective facilities and others. In order to reduce risks and damage, it is crucial to reduce the identified anthropogenic causes of floods in the Bosna River Basin, but also to replace poor agricultural practices with better ones that will adapt to the circumstances, stop unplanned construction in flood risk zones and stop deforestation. To conclude, it is necessary to emphasize the importance of appropriate afforestation measures, which would return the forest to its significant place in the hydrological cycle.

\section{REFERENCES}

Allen-Dumas, M. R., Xu H., Kurte, K. R., Rastogi, D. (2021) Toward Urban Water Security: Broadening the Use of Machine Learning Methods for Mitigating Urban Water Hazards, Frontiers in Water, 2 https://doi.org/10.3389/frwa.2020.562304

ARSO (2014) Environmental Agency of the Republic of Slovenia 2014, Analysis of the flood event in May 2014 in Bosnia and Herzegovina for the Bosnia River Basin within the additional assistance of the Republic of Slovenia - Report, Ljubljana, 2014.

Assessment of the endangerment of the territory of Zenica-Doboj Canton from natural and other disasters (Procjena ugroženosti teritorije Zeničko-Dobojskog Kantona od prirodnih i drugih nesreća), Zenica. http://www.zdk.ba/sjednicevlade/sjednice2016/63sjednica/63-16_21-07-2016.pdf (Accessed March 28 2021)

Barredo, J. I. (2007) Major flood disasters in Europe: 1950-2005. Natural Hazards 42, $125-148$. https://doi.org/10.1007/s11069-006-9065-2

Berz, G. (2000) Flood disasters: lessons from the past-worries for the future, Proceedings of the Institution of Civil Engineers - Water and Maritime Engineering 142 (1), 3 - 8. https://doi.org/10.1680/wame.2000.142.1.

Bonacci, O. (2003) Ecohydrology of water resources and open watercourses, (Ekohidrologija vodnih resursa $i$ otvorenih vodotoka), Faculty of Civil Engineering and Architecture, University of Split and IGH d.d. Zagreb.

Brunner, W.G. (2016) HEC-RAS, River Analysis System Hydraulic Reference Manual, U.S. Army Corps of Engineers, Institute for Water Resources, Davis.

Dingman S.L. (2009) Fluvial Hydraulics, Oxford University Press Inc, Oxford p. 570

Eriksson, M., Nutter, J., Day, S., Guttman, H., James, R., and Quibell, G. (2015) Challenges and commonalities in basin-wide water management. Aquatic Procedia 5, 44-57. https://doi.org/10.1016/j.aqpro.2015.10.007

Final results of the Census 2013 (Konačni rezultati Popisa 2013) http://fzs.ba/index.php/popisstanovnistva/popis-stanovnistva-2013/konacni-rezultati-popisa-2013/ (Accessed March 25 2021)

Gavrilović, Lj., Milanović Pešić, A. \& Urošev, M. (2012). A Hydrological Analysis of the Greatest Floods in Serbia in the 1960-2010 Period. Carpathian Journal of Earth and Environmental Sciences, 7 (4), $107-116$.

Győri, M. M., Haidu, I., Humbert, J. (2016) Deriving the floodplain in rural areas for high exceedance Probability Having limited data source. Environmental Engineering and Management Journal, 15, 1879-1887. https://doi.org/10.30638/EEMJ.2016.201

Haidu, I., Batelaan, O., Crăciun, A.I., \& Domnița, M. (2017) GIS module for the estimation of the hillslope torrential peak flow, Environmental Engineering and Management Journal, 16 (5), 1137-1144.

Haidu, I., Ivan, K. (2016). Évolution du ruissellement et du volume d'eau ruisselé en surface urbaine. Étude de cas: Bordeaux 1984-2014, France. La Houille Blanche. https://doi.org/10.1051/lhb/2016050

Hydrological study of surface waters of Bosnia and Herzegovina, Bosnia River Basin, Main document, 2012. Water Management Institute d.d. Sarajevo, Federal Hydrometeorological Institute (Hidrološka studija površinskih voda Bosne i Hercegovine, Sliv rijeke Bosne, Glavna knjiga, „Zavod za vodoprivredu“ d.d. Sarajevo, Federalni hidrometeorološki zavod), Sarajevo. 
Hydrological yearbook 2014., Hydrometeorological Institute of Republica Srpska (HMIRS) and Hydrometeorological Institute of Federation of Bosnia and Herzegovina (HMIFB\&H), http://www.fhmzbih.gov.ba/podaci/hidro/godisnjak/2014\%20godina.pdf

Imamović, A. (2015) Causes of floods in the Bosna River Basin with reference to the floods in May 2014, Flood risk management and mitigation of their harmful consequences (Uzroci poplava u slivu rijeke Bosne $\mathrm{s}$ osvrtom na poplave u maju 2014. godine), ANUBIH. https://doi.org/10.5644/PI2015-161-11

Jabučar, D., Lukovac, N. (2015) Implementation of the EU Floods Directive in BiH, Flood risk management and mitigation (Implementacija EU Direktive o poplavama u $\mathrm{BiH}$, Upravljanje rizicima od poplava $i$ ublažavanje njihovih štetnih posljedica), p. 256-266, https://doi.org/10.5644/PI2015-161-24

Jovanović, M., Prodanović D., Plavšić, J., Rosić N., Srna P., Radovanović M. (2014) Problems in making flood risk maps, Water Management 46 (Problemi pri izradi karata ugroženosti od poplava) 267-272.

Jovanović, M., Todorović, A. \& Rodić, M. (2009) Flood risk mapping. Water management Vol 41., No. 1-3 (Kartiranje rizika od poplava).

Khan, U.T., He J., Valeo C. (2018) River flood prediction using fuzzy neural networks: an investigation on automated network architecture, Water Science \& Technology, 2017, 1, $238-247$. https://doi.org/10.2166/wst.2018.107

Kim, V., Tantanee, S., Suparta, W. (2020) Gis-Based Flood Hazard Mapping Using Hec-Ras Model: A Case Study of Lower Mekong River, Cambodia, Geographia Technica, Vol 15, Issue no.1/2020, pp. 16-26, https://doi.org/10.21163/GT_2020.151.02

Koem, Ch., Tantanee, S. (2021) Flood Disaster Studies: A Review of Remote Sensing Perspective in Cambodia, Geographia Technica, Vol 16, Issue 1, 2021, pp. 13-24, https://doi.org/10.21163/GT 2021.161.02

Lozzi-Kožar, D., Kožar, I. (2009) Determination of flow resistance coefficient, Građevinar 61 (2009) 6, pp. 547556

Lumbroso, D., Gaume, E. (2012) Reducing the uncertainty in indirect estimates of extreme flash flood discharges, J. Hydrol., 414-415, pp. 16-30, https://doi.org/10.1016/j.jhydrol.2011.08.048

Mandych, A. F. (2010). Classification of Floods (Chapter), Encyclopedia of Life Support. Natural Disasters Vol. II, ed. W.M. Kotlyakov, UNESCO, Eolss Pbl. Co., 63-88.

Merz, B., Hall, J., Disse, M., and Schumann, A. (2010) Fluvial flood risk management in a changing world. Natural Hazards and Earth System Sciences 10, 509-527, https://doi.org/10.5194/nhess-10-509-2010

Ozkan, S. P., Tarhan, C. (2016) Detection of Flood Hazard in Urban Areas Using GIS: Izmir Case, Procedia Technology 22, 373 - 381., https://doi.org/10.1016/j.protcy.2016.01.026

Photo: Flooded area in May 2014, Municipality of Doboj-Jug, http://www.dobojjug.ba/contents/893 (Accessed 3rd April 2021)

Petrović, A. M., Dragićević, S. S., Radić, B. P., Milanović Pešić, A. (2015). Historical torrential flood events in the Kolubara river basin. Natural Hazards 79, 537-547. https://doi.org/10.1007/s11069-015-1860-111

Školjić, R., Hodžić, N. (2018) Implementation of projects in the Zenica-Doboj Canton, Water and me, No. 97 (Realizacija projekata u Zeničko-dobojskom kantonu)

The Report of the Cantonal Commission for Damage Assessment from Natural and other Damage on Damage assessment in the area of Zenica-Doboj Canton (Izvještaj Komisije za procjenu šteta od prirodnih i drugih neseća o procjeni šteta na području Zeničko - dobojskog kantona) http://zdk.ba/sjednicevlade/sjednice2015/18sjednica/18-04_20-07-2015.pdf (Accessed March 28 2021) 